\title{
Книжная полка
}

\section{К ВЫХХДУ СБОРНHКА *МЕХДУНАРОДНОЕ ГУМАНИТАРНОЕ ПРАВО В ДОКУМЕНТАХ (MOcKЕa, 1996)}

Издание сборника «Мехдународное гуманитарное право в документах» следует считать весьма своевременным. Интерес $\mathbf{k}$ этой отрасли права и в научных хругах, и среди юристов-практиков стабильно сохраняется на достаточно высохом уровне. А в последние годы отмечается заметный рост внимания $\mathbf{x}$ гуманитарному праву. Составители сборника ставили перед собой задачу наделить студентов, аспирантов, ученых-юристов и практических работников, интересующихся данной областью, необходнмым инструментарием для работы и, вне сомнения, хорошо с ней справились. Они исходили из концепции мехдународного гуманитарного права (МГTI) хах отрасли, объединяющей не тольхо нормы, применяемые в период ведения вооруженных действий, но и правовые нормы, регулируюшие отношения, связанные с правами человека в целом. Следует, однако, иметь в виду, что полемика по данному вопросу в наухе не закончена. Широкое распространение получала также концепция понимания МГП как свода правовых норм, применяемых исключительно в период военных действий. Этой трахтовхи придерхивается в своей деятельности Мехдународный комитет Красного Креста при осуществлении гуманитарной деятельности.

Сборник получился содерхательным, при этом надо учесть, что подобное издание впервые выходит в России, что делает его заметным событием.

Первая часть сборниха содержит основные дохументы в области обеспечения прав человека. Ценность представляет, наряду с такими документами, ках Международная хартия прав человека, публикашия в сборнике Конвенции Совета Европы о защите прав человека и основных свободах (в том виде, как ее подписала Россия), а также ряда протоколов $\mathrm{x}$ этой конвенции. Очевидно, что после вступления России в Совет Европы интерес $\mathbf{x}$ данной проблематике у юристов существенно возрастет. Наличие в одном издании ках универсальных, так и европейских основных документов по правам человека делает сборник значительным подспорьем 
для студентов, изучающих вопросы нормативного регулирования прав человека на юридических факультетах. В этой связи данный сборник интересен и полезен не только профессиональным юристам-международникам, но и весьма широкому кругу специалистов и читателей, интересующихся вопросами прав человека, правозащитной деятельностью.

Вторую часть сборника составляют документы мехдународного гуманитарного права, применяемого в период вооруженных конфликтов. В первую очередь следует выделить публикацию четырех Женевских конвенций о защите жертв войны и двух Дополнительных протоколов $\mathrm{x}$ ним. Эти мехдународные договоры являются базисными документами, и изучение права воорухенных конфликтов немыслимо без знания их положений. Однако зачастую библиотеки юридических факультетов страны не имеют в достаточном количестве техстов Женевских конвенций, и рецензируемый сборник способствует исправлению слохившейся ситуации.

В третьей части значительное внимание уделено персональной ответственности лиц, виновных в преступлениях против мира и человечности. Среди других документов опубликованы Уставы международных трибуналов по бывшей Югославии и Руанде. Большой интерес специалистов, ученых и практических работников $\mathrm{k}$ деятельности трибуналов вполне закономерен. Данные документы дают представление о реализации международного правосудия, что полезно для изучающих международное право.

Завершают сборник два документа, принятых в рамках $\mathrm{CH \Gamma :} \mathrm{о}$ правах и основных свободах человека и о первоочередных мерах по защите жертв вооруженных конфликтов на территории СНГ. Эти документы подтверждают, что начало процесса формирования гуманитарного права СНГ положено и теперь большое значение имеет его дальнейшее развитие.

K сожалению, отдельные документы, опубликованные в сборнике, $\mathbf{x}$ моменту выхода из печати утратили свою актуальность. Это, в частности, касается II «минного» протокола К Конвенции 1980 года «O запрещении или ограничении применения хонкретных видов обычного оружия, которые могут считаться наносящими чрезмерные повреждения или имеющими неизбирательное действие». На завершившейся 3 мая 1996 г. в Женеве Мехдународной конференции по пересмотру этой конвенции была прннята новая редахция «минного протокола. Этот документ вводит по сути новый, весьма подробно изложенный в протоколе рехим использования противопехотных мин. Кроме того, принят IV протокол этой конвенции, посвященный ослепляющим лазерам. Эти документы бесспорно являются дальнейшим шагом в развитии и углублении 
мехдународно-правовых норм, направленных на ограничение использования обычных видов вооружений неизбирательного действия, запрещенных $\mathbf{x}$ применению.

В целом следует отметить, что издание сборника «Международное гуманитарное право в документах» является первым русскоязычным изданием такого рода. В первую очередь он будет полезен студентам юридических факультетов университетов и институтов, высших учебных заведений Министерства внутренних дел, Федеральной службы безопасности, Министерства обороны РФ.

В заключение хотелось бы отметить слишком небольшой тираж издания - 2 тыс. экземпляров. Этого, конечно же, недостаточно, чтобы покрыть весь спрос на даннуго книгу.

C.Ю. К у з мен н ов, aтrame Правового департамента МИД РФ

\section{РОЛЬ МЕХДУНАРОДНОГО ПРАВА В НАШЕЙ ЖИЗНИ (к выходу в свет брошюры Г.И. Морозова "Международное право и международные отношения (проблемы взаимосвязи)")}

Институт мировой эхономики и международных отношений РАН издал (при финансовой поддержке английского общества за глобальную социальную и экономичесхую интеграцию) брошюру «Международное право и мехдународные отношения (проблемы взаимосвязи)» (М., 1997, 69 с.), написанную маститым российским юристом-международником, заслуженным деятелем науки РФ, доктором юридических наук, профессором Г.И. Морозовьм. Автором предисловия выступил член-корреспондент РАН, заместитель директора названного выше института О.Н. Быков.

Оценку этого события в отечественной общественной науке хочется начать с предварительных хомментариев. Во-первых, создание не прихладных, а фундаментальных теоретических работ является сегодня своеобразным подвижничеством. Такие труды не могут претендовать на массовую тиражность, и их издание, как следствие, не является прибыльным. Логика предельно проста не востребовано массами населения, не дает прибыли, а значит, не подлехит изданию. Между тем есть и другая логика - не развивается фундаментальная наука, нельзя ожидать успехов в решении прикладных вопросов. Когда весьма низкооплачиваемый главный 